difficult to decide which suprarenals are in the more physiological condition.

The noradrenaline used in these experiments was kindly given by Dr. H. Blaschko of the Department of Pharmacology, Oxford, and Dr. M. L. Tainter of Sterling Winthorp Research Institute.

This work was done during the tenure of a personal grant from the Medical Research Council.

Physiological Laboratory, Pamela Holton Cambridge. Jan. 16.

I von Euler, U. S., Ergeb. Physiol., 46, 261 (1950).

2 Holton, P., Nature, 163, 217 (1949).

- Holton, P., $J$. Physiol, 108, 525 (1949).

t von Euler, U. S., Nature, 163, 642 (1949).

\section{Zinc Content of the Genital Organs of the Rat}

IN a recent review, Vallee and Altschule ${ }^{1}$ have suggested that though many workers have estimated zine in living tissues, the methods used have often been inaccurate. We have estimated the zinc content of certain tissues of the Collip hooded rat by the dithizone method of Vallee and Gibson ${ }^{2}$. Mature animals were used which were fed on a diet of fox chow containing about $75 \mu \mathrm{gm}$. zine per gm., supplemented with carrot and cabbage. Most tissues contained about 15-30 $\mu \mathrm{gm}$. zine per gm.; but certain male genital organs showed wide deviations from this range. The literature contains few references to the zinc content of the genital system, though Bertrand and Vladesco ${ }^{3}$ reported high results in herring's and horse's testis, pig's seminal vesicle, rat's epididymis and in the prostate of the bull and of man. Kadota ${ }^{4}$ mentioned briefly that zinc could be detected by a relatively insensitive histochemical method in the rabbit prostate. The figures given by Leiner and Leiner $^{5}$ for rat's testis and by Eggleton ${ }^{6}$ for human testis were within the usual range for soft mammalian tissues.

The accompanying table shows the results we have obtained with the genital organs of the rat, compared with a selected group of other tissues of the rat. The amount of zine in the seminal vesicle contents was at the lower limit of accuracy of the method of estimation, and some of the zine found may have been due

\begin{tabular}{|c|c|c|c|}
\hline Organ & $\begin{array}{l}\text { No. of } \\
\text { samples }\end{array}$ & $\begin{array}{c}\text { Zine content of } 0 \\
\text { standard de } \\
(\mu \mathrm{gm} \text {./gm. wet } \\
\text { weight })\end{array}$ & $\begin{array}{l}\text { gan (mean with } \\
\text { viation) } \\
\text { (migm./gm. ash) }\end{array}$ \\
\hline $\begin{array}{l}\text { Seminal vesicle } \\
\text { contents } \\
\text { Seminal vesicle } \\
\text { tissue } \\
\text { Posterior prostate } \\
\text { Ventral prostate } \\
\text { Epididymis } \\
\text { Coagulating gland } \\
\text { Testis }\end{array}$ & $\begin{array}{r}5 \\
11 \\
9 \\
8 \\
6 \\
7\end{array}$ & $\begin{array}{r}2 \cdot 15 \pm 0.48 \\
22 \cdot 1 \pm 2.64 \\
180 \cdot 0 \pm 45.5 \\
13.7 \pm 3 \cdot 24 \\
46.2 \pm 4.60 \\
25.0 \pm 8.47 \\
28.9 \pm 1.84\end{array}$ & $\begin{array}{r}0.42 \pm 0.09 \\
1.98 \pm 0.30 \\
15 \cdot 2 \pm \pm .62 \\
1.49 \pm 0.43 \\
4.36 \pm 0.50 \\
2.49 \pm 0.81 \\
2.68 \pm 0.23\end{array}$ \\
\hline $\begin{array}{l}\text { Uterus } \\
\text { Ovaries }\end{array}$ & $\begin{array}{l}6 \\
5 \\
\end{array}$ & $\begin{array}{l}14.4 \pm 3.23 \\
20.3 \pm 1.49 \\
\end{array}$ & $\begin{array}{l}1.47 \pm 0.33 \\
1.51 \pm 0.23\end{array}$ \\
\hline $\begin{array}{l}\text { Brain } \\
\text { Liver } \\
\text { Lung } \\
\text { Submaxillary } \\
\text { gland } \\
\text { Pancreas } \\
\text { Duodenum } \\
\text { Diaphragm } \\
\text { Tibia }\end{array}$ & $\begin{array}{l}5 \\
5 \\
8 \\
5 \\
5 \\
6 \\
5 \\
5 \\
5\end{array}$ & $\begin{array}{r}14.8 \pm 1.32 \\
30.3 \pm 1.57 \\
18.7 \pm 1.61 \\
16.5 \pm 0.96 \\
23.3 \pm 1.01 \\
23.9 \pm 1.10 \\
24.9 \pm 2.51 \\
233.0 \pm 22.0\end{array}$ & $\begin{array}{l}1.06 \pm 0.08 \\
2 \cdot .23 \pm 0.12 \\
1.59 \pm 0.16 \\
1.17 \pm 0.06 \\
1.28 \pm 0.16 \\
1.93 \pm 0.28 \\
2.17 \pm 0.08 \\
0.39 \pm 0.05\end{array}$ \\
\hline
\end{tabular}

to contamination by vesicular tissue juice. There is no doubt, however, that this material contained much less zine than any other tissue examined. The posterior prostate, on the other hand, contained much more zine than any other tissue except bone, and, when results were calculated as zinc per gm. ash, the posterior prostate was by far the richest source of zinc in the body. The epididymis also contained a considerable amount of zinc; but the female genital organs gave no striking results.

It is noteworthy that the ventral prostate of the rat contained comparatively little zinc. The fact that the ventral and posterior prostates are very different tissues does not appear to be widely recognized, though they differ not only in gross and histological appearance but also in citric acid and fructose content ${ }^{7}$ and in acid and alkaline phosphatase activity ${ }^{8}$.

By the courtesy of Prof. Lyman Duff, of Montreal, and Prof. W. L. Robinson, of Toronto, we have been able to examine a number of specimens of human prostate taken at operation and at autopsy. The results, which will be reported elsewhere, were very variable; but most of the apparently normal glandular tissue contained more than $100 \mu \mathrm{gm}$. zinc per gm., and one value of $307 \mu \mathrm{gm}$. per gm. was observed. Four rabbit prostates contained 173, 233, 270 and $358 \mu \mathrm{gm}$. zinc per gm. It seems likely, therefore, that an exceptionally high zinc content is typical of the prostate gland.

C. A. Mawson

M. I. Fischer

Atomic Energy Project, Chalk River,

Ontario.

Dec. 21.

1 Vallee, B. L., and Altschule, M. D., Physiol. Rev., 29, 370 (1949).

${ }^{2}$ Vallee, B. L., and Gibson, J. G., J. Biol. Chem., 17B, 435 (1948).

${ }^{3}$ Bertrand, G., and Vladesco, R., C.R. Acad. Sci., Paris, 173, 176 (1921).

- Kadota, I., J. Lab. Clin. Med., 35, 568 (1950).

${ }^{5}$ Leiner, M., and Leiner, G., Naturwiss., 29, 763 (1941).

- Eggleton, W. W. E., Biochem. J., 34, 991 (1940).

7 Humphrey, G. F., and Mann, T., Nature, 161, 352 (1948).

Mawson, C. A., and Clayton. B. P. (unpublished).

\section{Detection of Enzymes by the Agar-Plate Method and its Application to Paper Chromatography}

IN previous publications ${ }^{1-4}$ from this laboratory, the use of the agar-plate method for the detection of enzymes has been described. This technique has now been adapted to the location of enzymes on paper. Preliminary investigations have shown that enzymes can be readily identified on the chromatogram by means of this technique.

The filter paper chromatographic experiments were carried out on paper strips (Whatman No. $1,40 \mathrm{~cm}$. $\times$ $12 \mathrm{~cm}$.) by a procedure which resembles in general that developed by Consden, Gordon and Martin ${ }^{5}$. The paper carrying the enzyme near its upper end is hung from a glass trough containing aqueous alcohol or aqueous acetone ( 50 per cent) as solvent, the whole system being kept in a rectangular-sided glass jar saturated with the vapour of the solvent. After a suitable time of running $(5-18 \mathrm{hr}$.), the paper is removed and the solvent front marked; the paper is allowed to dry at room temperature. The paper chromatogram is then placed on the surface of a thin layer of agar (2 per cent) containing the substrate. After a few hours (2-8 hr.) 